\title{
PENGAWASAN PERATURAN DAERAH SETELAH PUTUSAN MAHKAMAH KONSTITUSI NOMOR 137/PUU-XIII/2015 DAN 56/PUU-XIV/2016
}

\author{
Riza Novandra \\ Universitas Airlangga \\ riza.nvan@gmail.com
}

\begin{abstract}
Constitutional Court Decision Number 137 / PUU-XIII / 2015 and 56 / PUUXIV/ 2016 have abolished the supervise authority owned by the Central Government, especially in the case of the annulment of Local Regulations. The Minister of Home Affairs can no longer annul the Provincial Regulations, and the Governor as the representative of the central government in the regions, no longer has the authority to annul the Regency/ City Local Regulations that are considered problematic. The absence of repressive supervision from the Central Government on local regulations can certainly influence the implementation of a national policy when it reaches the region. In addition, the quality of Local Regulation itself, still far from ideal conditions and also has the potential to cause harm to the community. Whereas the Government's efforts in providing legal protection to the public will be severely hampered without the authority to overturn regional regulations. This study intends to analyze regional regulations in terms of their supervision. The study examines forms of supervision of local regulations that can be used by the Central Government. This study concluded that after the Constitutional Court Decisions, there is still a supervise authority that can be implemented by the Central Government. In addition to the need for strengthening the preventive supervision mechanism, there are other supervise instruments that can be used by both the Central Government and the local community itself.
\end{abstract}

Keywords: Local Autonomy, Local Regulations, Supervision.

\begin{abstract}
Abstrak
Putusan Mahkamah Konstitusi Nomor 137/PUU-XIII/2015 dan 56/PUUXIV/2016 telah menghapuskan kewenangan pengawasan yang dimiliki oleh Pemerintah Pusat khususnya dalam hal pembatalan Peraturan Daerah. Menteri Dalam Negeri kini tidak lagi dapat membatalkan Peraturan Daerah Provinsi, dan Gubernur sebagai wakil pemerintah pusat di daerah, tidak lagi mempunyai kewenangan untuk membatalkan Peraturan Daerah Kabupaten/ Kota yang dianggap bermasalah. Tidak adanya lagi pengawasan yang bersifat represif dari Pemerintah Pusat terhadap peraturan daerah tentunya dapat mempengaruhi implementasi dari sebuah kebijakan nasional ketika sampai di daerah. Di samping itu, kualitas Peraturan Daerah yang masih jauh dari kondisi ideal juga berpotensi menimbulkan kerugian bagi masyarakat. Sedangkan upaya Pemerintah dalam memberikan perlindungan hukum kepada masyarakat akan menjadi sangat terhambat tanpa adanya kewenangan untuk membatalkan peraturan daerah.
\end{abstract}


Penelitian ini hendak menganalisis peraturan daerah dari segi pengawasannya. Penelitian ini akan mengkaji bentuk pengawasan peraturan daerah yang dapat digunakan oleh Pemerintah Pusat. Penelitian ini berkesimpulan bahwa setelah adanya Putusan Mahkamah Konstitusi. masih terdapat kewenangan pengawasan yang dapat diterapkan oleh Pemerintah Pusat. Selain masih perlunya penguatan mekanisme pengawasan preventif, terdapat instrumen pengawasan lain yang dapat digunakan baik oleh Pemerintah Pusat maupun masyarakat daerah itu sendiri.

Kata Kunci: Otonomi Daerah, Peraturan Daerah, Pengawasan.

\section{Pendahuluan}

UU Nomor 23 Tahun 2014 tentang Pemerintahan Daerah secara eksplisit telah memberikan kewenangan kepada Mendagri dan Gubernur secara berjenjang untuk membatalkan Perda yang bertentangan dengan peraturan perundang-undangan yang lebih tinggi, kepentingan umum dan/ atau kesusilaan. Pembatalan suatu Perda merupakan kewenangan pemerintah dalam kaitannya melaksanakan proses pengawasan kepada daerah (Sihombing, 2017:218).

Namun demikian, terbitnya Putusan Mahkamah Konstitusi (MK) Nomor 137/PUU-XIII/2015 dan 56/PUUXIV/2016 telah membawa perubahan yang signifikan dalam penyelenggaraan Pemerintahan Daerah. Awalnya, Putusan MK Nomor 137/PUU-XIII/2015 mengabulkan pengujian ketentuan
Pasal 251 ayat (2), ayat (3), ayat (4) dan ayat (8) UU Nomor 23 Tahun 2014. Melalui putusan tersebut, MK menghapuskan wewenang Mendagri dan Gubernur sebagai wakil Pemerintah Pusat di daerah untuk membatalkan Perda Kabupaten/ Kota yang dianggap bermasalah.

Dalam perkembangan selanjutnya, seolah melengkapi Putusan tersebut MK kemudian mengeluarkan Putusan Nomor 56/PUUXIV/2016 yang pada pokoknya memutuskan bahwa pemerintah pusat kini tidak lagi memiliki kewenangan untuk melakukan pembatalan Perda Provinsi. Putusan MK Nomor 56/PUUXIV/2016 tersebut mengabulkan sebagian uji materi terhadap ketentuan Pasal 251 ayat (1), ayat (2), ayat (7), dan ayat (8) UU Nomor 23 Tahun 2014 tentang Pemerintahan Daerah. 
Padahal, selama ini upaya penyelarasan dan harmonisasi antara kebijakan yang ada di tingkat Pusat dengan kebijakan di Daerah salah satunya dilakukan melalui mekanisme pembatalan Perda sebagaimana diatur dalam UU Nomor 23 Tahun 2014. Pada tahun 2016 saja Mendagri telah membatalkan atau menolak sebanyak 3.143 Perda yang dianggap bermasalah mengganggu iklim ekonomi dan investasi (Kementerian Dalam Negeri, Daftar Perdal Perkada dan Peraturan Menteri Dalam Negeri yang

\section{Dibatalkan/Revisi}

http://www.kemendagri.go.id/media/ filemanager/2016/06/21/d/a/daftar_p erda-perkada_dan_permendagri _yang_dibatalkan_2016). Di satu sisi, banyaknya Perda yang dibatalkan tersebut mencerminkan kualitas regulasi di daerah yang masih jauh dari harapan pemerintah apalagi bagi masyarakat daerah itu sendiri. Terlebih lagi, hal ini akan sangat berpotensi menimbulkan ketidakpastian hukum serta permasalahan di daerah terlebih jika ditinjau dari aspek perlindungan hukum bagi masyarakat atas berlakunya suatu Perda.

Berdasarkan kondisi sebagaimana terurai di atas, menimbulkan permasalahan terkait implikasi hukum putusan MK terhadap pengawasan Perda. Bentuk pengawasan apa yang kini dapat diterapkan terhadap Perda?. Perlu diidentifikasi bentuk pengawasan yang dapat digunakan oleh Pemerintah Pusat kepada Pemerintah Daerah dalam kaitannya dengan pembentukan Perda.

Dalam rangka menjawab isu hukum yang diajukan, perlu dijelaskan terlebih dahulu beberapa landasan teori yang akan digunakan dalam pembahasan. Secara teoritis, pengawasan merupakan proses kegiatan-kegiatan yang membandingkan apa yang dijalankan, dilaksanakan, atau diselenggarakan itu dengan apa yang dikehendaki, direncanakan atau diperintahkan (Atmasudirjo, 1995: 84). Sedangkan dalam hal pengawasan terhadap peraturan perundang-undangan tidak dapat dilepaskan dari konsep hak atau kewenangan untuk menguji atau 
yang biasa dikenal dengan istilah "toetsingsrecht". Istilah "toetsingsrecht" diartikan sebagai "hak atau kewenangan untuk menguji" atau "hak uji" (Asshiddiqie, 2005:6). Pengertian tersebut memperjelas bahwa istilah "toetsingsrecht" merupakan suatu proses untuk melakukan pengujian atau menguji dan secara harfiah dapat diartikan sebagai kewenangan untuk menguji (Soebechi, 2016:49).

Pengertian menguji atau melakukan pengujian merupakan proses untuk memeriksa, menilai, dan memutuskan terhadap objeknya. Pemahaman menguji atau melakukan pengujian dalam dalam perspektif "toetsingsrecht" adalah memeriksa, menilai, dan memutuskan terhadap tingkat konstitusionalitas suatu peraturan perundang-undangan terhadap peraturan perundangundangan yang derajatnya lebih tinggi oleh suatu lembaga negara oleh Undang-Undang Dasar dan/ atau undang-undang diberikan kewenangan (Martosoewignjo, 1986:8).

Pengertian "toetsingsrecht" cukup luas, peristilahan yang timbul pun tergantung dari subjek dan objeknya. Dikaitkan dengan subjek, toetsingsrecht dapat dilekatkan pada lembaga kekuasaan negara yudisial, legislatif, dan eksekutif. Jika hak atau kewenangan menguji tersebut diberikan kepada lembaga kekuasaan kehakiman atau hakim, maka hal tersebut disebut "judicial review". Akan tetapi, jika kewenangan tersebut diberikan kepada lembaga legislatif, maka istilahnya menjadi “legislative review”. Demikian pula jika kewenangan itu diberikan kepada lembaga eksekutif, maka istilahnya juga menjadi "executive review" (Asshiddiqie, 2005:50).

Pada dasarnya pengawasan terhadap segala kegiatan pemerintahan daerah merupakan suatu akibat mutlak dari adanya negara kesatuan. Di dalam sebuah negara kesatuan tidak mengenal bagian yang lepas dari atau sejajar dengan negara, tidak mungkin pula ada negara di dalam negara. Bahkan dalam hal ini dapat dikatakan tidak ada pemerintahan berotonomi tanpa pengawasan (Sukriono, 2013:140). Jika ditinjau secara teoritis, terdapat dua jenis pengawasan yang 
dilakukan terhadap pemerintahan otonomi, yaitu pengawasan preventif dan pengawasan represif. Pengawasan ini berkaitan dengan produk hukum dan tindakan tertentu organ pemerintahan daerah. Pengawasan preventif dikaitkan dengan wewenang mengesahkan (goedkeuring), sedangkan pengawasan represif adalah wewenang pembatalan (vernietiging) atau penangguhan (schorsing) (Sukriono, 2013:141).

Pengawasan preventif terhadap Perda dilaksanakan melalui mekanisme executive preview. Executive preview Perda merupakan kewenangan yang diberikan kepada pemerintah untuk melakukan pengujian terhadap rancangan peraturan perundang-undangan (termasuk Perda) sebelum disahkan dan diundangkan (Soebechi, 2016:60).

Selain kewenangan preview sebagaimana telah diuraikan di atas, Pemerintah dalam hal pengawasan Perda juga dapat melakukan pengawasan yang bersifat represif (executive review). Pengawasan represif ini dapat dijalankan terhadap semua Perda apabila dianggap bertentangan dengan peraturan perundang-undangan yang lebih tinggi tingkatannya atau dengan kepentingan umum (Sukriono, 2013:142).

Berbicara mengenai pengawasan preventif dan pengawasan represif, I Gde Pantja Astawa menyatakan bahwa secara garis besar perbedaan antara keduanya adalah pengawasan preventif yang dilakukan sebelum perda disahkan, sedangkan pengawasan represif dilakukan setelah perda disahkan. Berdasarkan akibat hukumnya, pengawasan preventif belum menyentuh akibat hukum yang timbul karena status perda belum disahkan, sedangkan dalam pengawasan represif sudah memperhitungkan akibat hukum yang timbul pada saat keberlakuannya (Astawa, 2008:322323). Sementara itu, Bagir Manan berpendapat bahwa pengawasan preventif memiliki aspek positif, yaitu dapat mengendalikan inisiatif yang dilakukan oleh daerah, sehingga daerah dipaksa untuk mengikuti kebijakan dari pemerintah pusat (Manan, 2005:154). 
Pelaksanaan

pengawasan

preventif berada pada posisi "lebih awal" dari pengawasan represif. Daya campur tangan Pemerintah terhadap daerah juga menjadi lebih besar. Pengawasan preventif mengandung "prasyarat" agar perda di bidang atau yang mengandung sifat tertentu dapat dijalankan, artinya selama prasyarat tidak atau belum terpenuhi keputusan perda tidak dapat dijalankan. Sedangkan pengawasan represif dilaksanakan dalam bentuk menangguhkan berlakunya suatu perda dan membatalkannya.

Di samping pengawasan yang dilakukan oleh Pemerintah terdapat pengawasan yang dilaksanakan melalui mekanisme Judicial Review. Judicial review merupakan hak menguji (toetsingsrecht) dari kekuasaan yudikatif untuk melakukan pengujian terhadap peraturan perundang-undangan (Asshiddiqie, 2006:1-2). Fungsi judicial power dalam melakukan pengujian ini didasarkan pada kewenangan pengawasan sebagai konsekwensi dari prinsip check and balance antar organ pelaksana kekuasaan negara (Soebechi, 2016:65). Terkait hal ini Adnan Buyung Nasution menyatakan:

“...hak uji materiil atau judicial
review tidak bisa dilepaskan
dari independent judiciary,
karena judicial review
merupakan salah ratu
pelaksanaan independent
judiciary yang berdasar pada
doktrin trias politika yang
memisahkan kekuasaan
legislatif, eksekutif, dan
yudikatif. Hal ini berlaku
secara universal di negara
hukum manapun baik yang
menganut sistem common law
maupun civil law.” (Nasution,
2007:27).

Dalam konsep judicial review, lingkup pengujian dari judicial review sendiri tidak hanya terbatas pada pengujian peraturan perundangundangan. Judicial review juga mencakup pengujian tindakan hukum penguasa baik tindakan di luar kewenangannya atau karena pejabat publik tidak melakukan tindakan yang seharusnya dilakukan. Sebagaimana dinyatakan oleh Peter Crane dalam Imam Soebechi, bahwa selain mengacu pada keselarasan peraturan perundang-undang yang bertentangan dengan konstitusi dan treaty, judicial review juga berkenaan dengan kontrol kekuasaan 
kehakiman terhadap tindakan hukum pemerintah (Soebechi, 2016:66).

\section{Metode Penelitian}

Jenis penelitian yang digunakan adalah penelitian hukum normatif. Dalam hal ini penelitian tersebut merupakan suatu proses unuk menemukan aturan hukum, prinsipprinsip hukum, maupun doktrindoktrin hukum guna menjawab isu hukum yang dihadapi. Hasil yang dicapai adalah memberikan preskripsi mengenai apa yang seyogyanya atas isu yang diajukan.

Pendekatan yang digunakan dalam penelitian ini adalah pendekatan perundang-undangan (statute approach) dan pendekatan konseptual (conceptual approach). Pendekatan perundang-undangan (statute approach) dilakukan dengan menelaah semua undang-undang dan regulasi yang bersangkut paut dengan isu hukum yang dihadapi dengan mencari ratio legis lahirnya suatu peraturan perundangundangan. Sedangkan pendekatan konseptual (conseptual approach) dilakukan manakala peneliti tidak beranjak dari aturan hukum yang ada
(Marzuki, 2016:132-140). Dalam pendekatan ini pandanganpandangan dan doktrin-doktrin banyak digunakan sebagai salah satu acuan dalam memecahkan isu hukum yang sedang diteliti, antara berkenaan dengan konsep bentukbentuk pengawasan Perda.

\section{Hasil dan Pembahasan}

\section{Implikasi Hukum Putusan Mk} Terhadap Pengawasan Perda

Perda merupakan pilar utama yang memayungi realisasi otonomi daerah. Perda memiliki karakteristik bersifat mengatur (regelling), khususnya mengatur relasi antara pemerintah daerah, masyarakat lokal, stakeholders lokal seperti dunia usaha. Perda bukan hanya mengatur kehidupan politik, sosial dan budaya masyarakat, akan tetapi juga masalah ekonomi daerah. Oleh karena itu, Perda menjadi instrumen penting dalam meningkatkan perekonomian dan kesejahteraan daerah pada umumnya (Sirajuddin, 2016:185).

Perda yang dibentuk oleh DPRD dengan persetujuan bersama kepala Daerah pada dasarnya merupakan ciri khas dari pengejawantahan 
prinsip otonomi daerah berdasarkan asas desentralisasi. Di Indonesia, kewenangan pembentukan Perda yang dilakukan oleh pemerintahan daerah tersebut merupakan kewenangan atribusi sebagaimana telah ditentukan dalam Pasal 18 ayat (6) UUD NRI Tahun 1945. Kewenangan pembentukan Perda tetap harus sesuai dengan peran pemerintah daerah dalam konteks negara kesatuan, sehingga dalam pelaksanaannya tidak bebas namun terbatas oleh kekuasaan dari pemerintah pusat selaku pemegang kedaulatan tertinggi.

Jika dilihat dari materi muatannya Perda wajib didasarkan pada peraturan perundang-undangan yang lebih tinggi serta dilarang bertentangan dengan kepentingan umum dan/ atau kesusilaan. Hal ini kemudian membutuhkan adanya mekanisme pengawasan dari pemerintah agar Perda tetap berada di dalam koridor penyelenggaraan pemerintahan yang selaras dengan arah kebijakan Pemerintah Pusat.

Sehubungan dengan hal tersebut, mengingat otonomi daerah tidak bermakna sebagai sebuah kebebasan atau kemerdekaan daerah, maka dalam hal pemberian dan pelimpahan kewenangan kepada daerah harus disertai dengan adanya mekanisme pengawasan dari pemerintah pusat. Adapun bentuk dari keterikatan antara pemerintah pusat dan pemerintah daerah, terutama dalam menjalankan kewenangan pembentukan Perda adalah adanya mekanisme pengawasan yang berjenjang dari tingkat pemerintahan di atasnya.

Secara normatif pelaksanaan pengawasan terhadap Perda didasarkan pada UU Nomor 23 Tahun 2014 tentang Pemerintahan Daerah. Berlakunya UU Nomor 23 Tahun 2014 dapat dikatakan sebagai titik pijak penataan penyelenggaraan desentralisasi dan otonomi daerah, karena telah membawa angin perubahan baik pada ranah paradigma, pola dan fungsi utama penyelenggaraan pemerintahan daerah (Sirajuddin, 2016:185).

Jika mencermati ketentuanketentuan di dalam UU Nomor 23 Tahun 2014 terdapat 2 (dua) jenis pengawasan terhadap Perda, yaitu pengawasan yang bersifat preventif 
(preview) yang dalam hal ini dilaksanakan melalui mekanisme evaluasi Raperda dan juga pengawasan represif melalui mekanisme pembatalan perda (executive review).

Berkenaan dengan pengawasan preventif, sebagaimana diatur dalam ketentuan Pasal 245 UU Nomor 23 Tahun 2014 terdapat mekanisme evaluasi yang diberlakukan terhadap Raperda tentang RPJPD, RPJMD, APBD, Perubahan APBD, Pertanggungjawaban Pelaksanaan APBD, Pajak Daerah, Retribusi Daerah dan Tata Ruang Daerah. Terhadap beberapa jenis Raperda tersebut, harus mendapatkan evaluasi terlebih dahulu dari Menteri Dalam Negeri atau Gubernur sesuai dengan kewenangannya sebelum ditetapkan oleh Kepala Daerah.

Sementara itu, di tingkatan pengaturan yang lebih teknis, Mendagri telah menerbitkan Peraturan Menteri Dalam Negeri Nomor 80 Tahun 2015 tentang Pembentukan Produk Hukum Daerah. Di dalam Permendagri tersebut selain mengatur mengenai evaluasi peraturan daerah juga diatur mengenai fasilitasi Raperda sebagai bentuk pengawasan dalam rangka pembinaan. Berdasarkan ketentuan Pasal 87 dan Pasal 88 Permendagri Nomor 80 Tahun 2015, terhadap seluruh perda yang dibentuk oleh Pemerintahan Daerah yang tidak dilakukan evaluasi, maka wajib hukumnya untuk difasilitasi terlebih dahulu.

Dalam Permendagri Nomor 80 Tahun 2015 meskipun istilah yang digunakan adalah "pembinaan", akan tetapi jika istilah ini dikaitkan dengan konsep pengawasan, maka dapat dipahami bahwa essensi yang terkandung dalam pembinaan tersebut merupakan bentuk dari dilaksanakannya pengawasan preventif. Secara teoritis, pengawasan preventif itu berbentuk pengesahan atau tidak memberi (menolak) pengesahan. Pengawasan preventif dilakukan sesudah perda ditetapkan, tetapi sebelum perda itu mulai berlaku (Sukriono, 2013:141). Dengan kata lain perda, yang dikenakan pengawasan preventif hanya dapat mulai berlaku apabila keputusan itu telah lebih dahulu disahkan oleh penguasa yang 
berwenang mengesahkan. Menurut penulis, pelaksanaan fasilitasi terhadap Raperda ini dapat diartikan sebagai wujud dari penyelenggaraan pengawasan preventif (executive preview) yang dilakukan oleh Pemerintah kepada Pemerintah Daerah yang mana dilakukan terhadap raperda sebelum diundangkan.

Merujuk pada ketentuan Pasal 242 ayat (4) UU Nomor 23 Tahun 2014 dan Pasal 98 ayat (1) serta Pasal 99 ayat (1) Permendagri Nomor 80 Tahun 2015, setelah dilakukannya tahapan evaluasi atau fasilitasi dan terhadap materi muatan rancangan peraturan daerah telah ditindaklanjuti serta disempurnakan oleh pemerintah daerah dan telah ditetapkan, selanjutnya terhadap peraturan daerah tersebut diajukan kepada Menteri Dalam Negeri/ Gubernur sesuai dengan kewenangannya untuk kemudian mendapatkan nomor register peraturan daerah. Momentum pemberian nomor register oleh Menteri Dalam Negeri untuk Peraturan Daerah Provinsi, dan oleh Gubernur untuk Peraturan Daerah
Kabupaten/ Kota dapat dimanfaatkan sebagai proses 'double check' dari pemerintahan di atasnya untuk melakukan pencermatan kembali terhadap seluruh materi muatan peraturan daerah apakah telah dilakukan penyempurnaan sesuai dengan hasil evaluasi/ fasilitasi.

Sebelum adanya Putusan MK Nomor 137/PUU-XIII/2015 dan 56/PUUXIV/2016, UU Nomor 23 Tahun 2014 juga mengatur mengenai pengawasan represif (executive review) yang dapat dilihat dari rumusan ketentuan Pasal 251. Berdasarkan ketentuan Pasal 251 dalam prakteknya diwujudkan melalui mekanisme pembatalan perda. Jika suatu perda yang dibentuk oleh Pemerintah Daerah Provinsi dianggap bertentangan dengan ketentuan peraturan perundang-undangan yang lebih tinggi, kepentingan umum, dan/atau kesusilaan maka selanjutnya Mendagri dapat membatalkan perda tersebut dengan menetapkan Keputusan. Sama halnya terhadap Perda Kabupaten/ Kota, jika materi muatan yang diatur dinilai bertentangan dengan ketentuan 
peraturan perundang-undangan yang lebih tinggi, kepentingan umum, dan/atau kesusilaan maka Gubernur sebagai wakil Pemerintah Pusat berwenang untuk membatalkan Perda Kabupaten/Kota tersebut dengan menetapkan Keputusan Gubernur. Dalam ketentuan tersebut juga diatur bahwa dalam hal Gubernur tidak membatalkan Perda Kabupaten/Kota yang bertentangan dengan ketentuan peraturan perundang-undangan yang lebih tinggi, kepentingan umum, dan/atau kesusilaan maka Menteri dapat mengambil alih kewenangan tersebut untuk kemudian membatalkan Perda Kabupaten/Kota.

\section{Bentuk Pengawasan Pemerintah Pusat Terhadap Pembentukan Perda}

$\begin{array}{cc}\text { Terhadap } & \text { mekanisme } \\ \text { penyelenggaraan } & \text { pengawasan }\end{array}$
khususnya yang diatur dalam Pasal 251 UU Nomor 23 Tahun 2014 ternyata harus mengalami perubahan seiring dengan diterbitkannya Putusan MK Nomor 137/PUUXIII/2015 dan 56/PUUXIV/2016. MK dengan sifat putusannya yang erga omnes telah membawa konsekwensi terhadap sifat mengikatnya yang mana tidak hanya dan tidak harus selalu pembentuk UU, tetapi juga semua pihak yang terkait dengan ketentuan yang diputus oleh MK. Hal tersebut membawa akibat hukum yang sama dengan diundangkannya satu undang-undang. Itu berarti bahwa putusan tersebut mengikat seluruh warga negara, pejabat negara, dan lembaga negara (Laksono, 2013:910).

Pasca diterbitkannya Putusan MK, kini Mendagri tidak lagi dapat membatalkan Perda Provinsi/ Kabupaten/ Kota, dan juga telah mengakibatkan Gubernur sebagai wakil dari pemerintah pusat, untuk tidak lagi memiliki kewenangan membatalkan Perda kabupaten/kota yang dinilai bertentangan dengan ketentuan peraturan perundangundangan yang lebih tinggi, kepentingan umum, dan/atau kesusilaan.

Di satu sisi, pasca Putusan MK telah memposisikan MA sebagai satu-satunya lembaga yang dapat membatalkan keberlakuan sebuah 
perda melalui mekanisme Pengujian Peraturan Perundang-Undangan (Hak Uji Materiil/ Judicial Review). Mengingat sesuai dengan kewenangannya sebagaimana diatur dalam Pasal 24A ayat (1) UUD NRI Tahun 1945, Pasal 20 ayat (2) huruf b UU Nomor 48 Tahun 2009 tentang Kekuasaan Kehakiman dan Pasal 31 ayat (1) UU Nomor 14 Tahun 1985, MA berwenang mengadili pada tingkat kasasi, menguji peraturan perundang-undangan di bawah undang-undang in casu perda terhadap UU.

Sebagaimana dipahami bahwa Putusan MK Nomor 137/PUUXIII/2015 dan 56/PUUXIV/2016 telah membawa konsekuensi terhadap hapusnya kewenangan executive review yang dimiliki Pemerintah Pusat serta menempatkan MA sebagai satu-satunya lembaga yang dapat membatalkan Perda melalui mekanisme judicial review.

Perkembangan selanjutnya, di samping mekanisme judicial review di MA ternyata Kementerian Hukum dan Hak Asasi Manusia juga telah membuka alternatif penyelesaian sengketa peraturan perundang- undangan lain yakni melalui jalur nonlitigasi. Hal ini secara khusus diatur dalam Peraturan Menteri Hukum dan Hak Asasi Manusia (Permenkumham) Nomor 32 Tahun 2017 tentang Tata Cara Penyelesaian Sengketa Peraturan Perundangundangan Melalui Jalur Nonlitigasi.

Meskipun mekanisme penyelesaian sengketa ini dapat dimaknai sebagai upaya Pemerintah dalam rangka penataan regulasi agar harmonis dan tidak saling bertentangan, namun justru dibenturkan dengan kewenangan yudisial yang menjadi kewenangan pemegang kekuasaan kehakiman. Dengan kata lain, apakah mekanisme yang dilaksanakan oleh Kemenkumham tersebut tidak overlapping atau bahkan bertentangan dengan kewenangan yang dimiliki MA dalam melaksanakan judicial review?.

Terkait persoalan legalitas tersebut, jika mendasarkan pada UUD NRI Tahun 1945, ketentuan Pasal 4 ayat (1) menentukan bahwa Presiden adalah pemegang kekuasaan pemerintahan. Ketentuan ini memiliki makna bahwa 
penanggung jawab keseluruhan pelaksanaan pemerintahan adalah Presiden. Oleh karena itu, Presiden berkepentingan dan berdasar hukum untuk memastikan penyelenggaraan pemerintahan yang berada di bawah tanggung jawabnya. Dalam rangka menyelenggarakan pemerintahan, maka sesuai dengan ketentuan Pasal 17 ayat (1) dan ayat (3) UUD NRI Tahun 1945, Presiden dalam hal ini dibantu oleh menteri-menteri negara yang membidangi urusan tertentu dalam pemerintahan. Menurut Jimly, para menteri negara tunduk dan bertanggungjawab kepada presiden sebagai satu kesatuan institusi (Asshiddiqie, 2007:328-329).

Selanjutnya, menurut ketentuan Pasal 21 ayat (4), Pasal 23 ayat (2) huruf b, Pasal 26 ayat (1), Pasal 47 ayat (3), Pasal 49 ayat (3), Pasal 54 ayat (2), Pasal 55 ayat (2), Pasal 85 dan Pasal 91 UU Nomor 12 Tahun 2011 tentang Pembentukan Peraturan Perundang-Undangan telah mengatur bahwa menteri yang menyelenggarakan urusan pemerintahan di bidang hukum, yang dalam hal ini adalah Menkumham, memiliki kewenangan antara lain dalam hal pembentukan perundangundangan Prolegnas, pembahasan harmonisasi RUU, Rancangan Peraturan Pemerintah dan Peraturan Presiden, serta pengundangan.

Di samping itu, berdasarkan ketentuan Pasal 2 dan Pasal 3 huruf a Peraturan Presiden Nomor 44 Tahun 2015 tentang Kementerian Hukum dan Hak Asasi Manusia Republik sebagai turunan dari UU Nomor 39 Tahun 2008 tentang Kementerian Negara, menyebutkan bahwa Kemenkumham salah satunya mempunyai tugas menyelenggarakan urusan pemerintahan di bidang hukum serta memiliki fungsi perumusan, penetapan, dan pelaksanaan kebijakan di bidang peraturan perundang-undangan.

Berdasarkan uraian tersebut, penulis kemudian berpendapat bahwa penyelesaian sengketa nonlitigasi tersebut masih berada dalam koridor konstitusional mengingat dasar penyelenggaraan pemerintahan negara secara keseluruhan memang merupakan kewenangan presiden menurut ketentuan Pasal 4 ayat (1) UUD NRI Tahun 1945 yang dalam 
pelaksanaannya dibantu oleh Menteri berdasarkan Pasal 17 ayat (1) dan ayat (3) UUD NRI Tahun 1945. Oleh karena itu, jika dalam penyelenggaraan pemerintahan masih ditemukan adanya peraturan perundang-undangan yang saling bertentangan satu sama lain (termasuk Perda), tentunya hal ini menjadi tanggung jawab Presiden untuk melakukan pengawasan dan penataan regulasi yang dalam pelaksanaannya dibantu oleh Menkumham.

Di samping itu, jika mendasarkan pada "asas praduga keabsahan" (praesumtio iustae causa) yakni bahwa tindakan penguasa dianggap sah sesuai aturan hukum sampai ada pembatalannya. Berdasarkan asas ini, semua tindakan penguasa baik berupa produk hukum maupun tindakan konkret harus dianggap sah sampai ada pembatalan. Artinya, berbicara mengenai legalitas bagaimanapun juga hingga saat ini Permenkumham Nomor 32 Tahun 2017 tersebut harus dianggap sah dan tidak bertentangan dengan peraturan perundangundangan yang lebih tinggi sepanjang tidak dinyatakan sebaliknya oleh lembaga yang berwenang.

Ketentuan Pasal 2 ayat (1) Permenkumham Nomor 32 Tahun 2017 menyatakan bahwa:

"Peraturan Perundang-
undangan yang bertentangan
baik secara vertikal maupun
horizontal yang menyebabkan
timbulnya konflik norma
hukum, konflik kewenangan
antar kementerian/lembaga dan
pemerintah daerah yang
menimbulkan ketidak adilan
bagi masyarakat dan pelaku
usaha serta menghambat iklim
investasi, usaha, dan
kegiatan ekonomi nasional dan
daerah dapat diajukan
permohonan penyelesaian
sengketa melalui
jalur Nonlitigasi".

Adapun yang dapat mengajukan permohonan penyelesaian sengketa melalui jalur nonlitigasi menurut ketentuan Pasal 2 ayat (2) Permenkumham Nomor 32 Tahun 2017 adalah:

a) orang perseorangan atau kelompok orang;

b) badan/ lembaga/ kementerian/ lembaga pemerintah non kementerian/ pemerintahan daerah; dan 
c) swasta atau badan usaha publik/privat.

Penyelesaian sengketa menurut Permenkumham Nomor 32 Tahun 2017 tidak dapat dilepaskan begitu saja dari konsep hak menguji (toetsingrecht) yang merupakan wujud pengawasan dalam rangka menjaga kesatuan tatanan hukum antara satu peraturan perundangundangan dengan lainnya agar tidak terjadi pertentangan. Pengertian "toetsingsrecht" cukup luas, sehingga peristilahan yang timbul pun sangat tergantung dengan subjek dan objek dalam suatu pengujian. Dikaitkan dengan subjek, toetsingsrecht dapat dilekatkan pada lembaga kekuasaan negara yudisial, legislatif, dan eksekutif. Menurut Jimly Asshiddiqie, jika hak atau kewenangan menguji tersebut diberikan kepada lembaga kekuasaan kehakiman atau hakim, maka hal tersebut disebut "judicial review". Akan tetapi, jika kewenangan tersebut diberikan kepada lembaga legislatif, maka istilahnya menjadi "legislative review”. Demikian pula jika kewenangan itu diberikan kepada lembaga eksekutif, maka

istilahnya juga menjadi "executive review" (Asshiddiqie, 2005:50). Jika pemahaman secara teoritis mengenai toetsingsrecht di atas dikaitkan dengan kewenangan penyelesaian sengketa yang diatur dalam Permenkumham Nomor 32 Tahun 2017, maka pemeriksaan permohonan yang dilakukan oleh Kemenkumham sebenarnya juga dalam rangka melakukan pengujian (toetsingrecht) yang lebih tepatnya dapat dikategorikan sebagai executive review. Akan tetapi, bentuk review melalui mekanisme pemeriksaan yang dilaksanakan oleh Kemenkumham disini berbeda dengan pengawasan represif yang dapat menangguhkan atau membatalkan keberlakukan sebuah peraturan perundang-undangan.

Menurut penulis, penyelesaian sengketa berdasarkan Permenkumham Nomor 32 Tahun 2017 harus dipandang sebagai sebuah bentuk pengawasan (executive review) yang lebih bersifat korektif dalam bentuk rekomendasi dan bukan judicial review ala Kemenkumham yang dilakukan di luar pengadilan karena hal ini akan 
bertentangan dengan UUD NRI

Tahun 1945 khususnya Pasal 24A

ayat (1) dan Pasal 24C. Meskipun

dalam prakteknya sebagaimana diatur dalam ketentuan Pasal 5 ayat

(1) Permenkumham Nomor 32

Tahun 2017, Kemenkumham memang seolah mengadopsi sistem persidangan di pengadilan seperti memanggil pemohon untuk pemeriksaan substansi permohonan, lalu dilanjutkan dengan menghadirkan para pihak yang terkait dengan permohonan, serta menghadirkan ahli untuk memberikan pendapat hukum hingga menyimpulkan dan membacakan hasil pemeriksaan.

Mekanisme pengawasan berdasarkan Permenkumham Nomor 32 Tahun 2017 ini sangat jauh berbeda jika dibandingkan dengan executive review terhadap perda sebagaimana diatur dalam Pasal 251 UU Nomor 23 Tahun 2014 yang telah dibatalkan oleh MK. Perbedaan dimaksud salah satunya adalah mengenai hasil pemeriksaan yang hanya berupa laporan dan rekomendasi. Hal ini dapat dilihat dalam ketentuan Pasal 6
Permenkumham Nomor 32 Tahun 2017 yang selengkapnya menyatakan sebagai berikut:

Pasal 6

(1) Berdasarkan hasil pemeriksaan permohonan sebagaimana dimaksud dalam Pasal 5, Direktur Jenderal menyampaikan laporan hasil pemeriksaan secara tertulis kepada:
a. Menteri;
b. pemohon; dan
c. badan/lembaga/kementerian $/ 1$
embaga pemerintah nonkementerian/ pemerintahan daerah terkait.

(2) Menteri menyampaikan laporan hasil pemeriksaan sebagaimana dimaksud pada ayat (1) kepada Presiden disertai dengan rekomendasi.

(3) Rekomendasi sebagaimana dimaksud pada ayat (2) dapat berupa:
a. mencabut Peraturan Perundang-undangan;
b. mengubah Peraturan Perundang-undangan; atau
c. membentuk Peraturan Perundang-undangan baru.

Hasil pemeriksaan penyelesaian sengketa ini adalah berupa laporan dan rekomendasi kepada Presiden untuk mencabut, mengubah atau bahkan membentuk peraturan perundang-undangan baru manakala terjadi konflik norma hukum, konflik kewenangan antar kementerian/lembaga dan 
pemerintah daerah yang dalam judicial review yang hasilnya menimbulkan ketidakadilan bagi berupa putusan serta bersifat final masyarakat dan pelaku usaha serta menghambat iklim investasi, usaha, dan kegiatan ekonomi nasional dan daerah. Di satu sisi, rekomendasi ini dinilai kurang memiliki daya ikat. Namun penulis beranggapan jika berangkat dari adanya Putusan MK, tentunya dapat dipahami bahwa bentuk rekomendasi ini merupakan salah satu pilihan yang tepat karena keputusan terkait tindak lanjut atas hasil pemeriksaan sengketa akan dikembalikan kepada Presiden selaku pemegang kekuasaan tertinggi pemerintahan. Dengan kata lain, Menkumham dalam hal ini tidak membatalkan secara sepihak terhadap perda yang dianggap bermasalah dan dimohonkan untuk dilakukan pemeriksaan. Hal ini sangat berbeda dengan Mendagri atau Gubernur yang kala itu dapat langsung membatalkan perda dengan menetapkan Keputusan.

Harus dipahami bahwa dalam konteks penyelesaian sengketa peraturan perundang-undangan nonlitigasi memang bukan dalam rangka memutus seperti halnya and binding. Sehingga mekanisme review yang diatur dalam Permenkumham Nomor 32 Tahun 2017 ini menurut penulis juga tidak melampaui, menegasikan atau mengambilalih kewenangan MA dan MK dalam melakukan judicial review yang telah dijamin dalam UUD NRI Tahun 1945 khususnya Pasal 24A ayat (1) dan Pasal 24C.

Bagaimanapun juga kehadiran Permenkumham Nomor 32 Tahun 2017 setidaknya dapat dimaknai sebagai sebuah jawaban dari pemerintah atas persoalan kebutuhan penataan regulasi di Indonesia. Kebutuhan akan pengawasan terhadap peraturan perundangundangan yang dilaksanakan dalam rangka menjamin kebijakan agar dapat lurus hingga ke daerah, telah mendorong Pemerintah untuk berupaya menciptakan terobosan dalam mekanisme pengawasan. Kebijakan Kemenkumham membuka ruang penyelesaian sengketa peraturan perundang-undangan melalui jalur nonlitigasi merupakan 
inisiatif yang baik di tengah peliknya permasalahan regulasi di Indonesia.

Berkenaan dengan permasalahan regulasi, Ida Bagus Rahmadi Supanca menyebutkan kondisi kualitas regulasi di Indonesia, sebagai berikut (Supanca, 2017:2-4):

1) Terlalu banyaknya Regulasi (Hyper-regulation);

2) Saling Bertentangan (Conflicting);

3) Tumpang Tindih (Overlapping);

4) Multi Tafsir (Multi Interpretation);

5) Tidak Taat Asas (Incosistency);

6) Tidak Efektif;

7) Menciptakan Beban yang Tidak Perlu (Unnecessary Burden); dan

8) Menciptakan Ekonomi Biaya Tinggi (High-Cost Economy).

Sementara itu, pengawasan oleh Pemerintah terhadap perda pasca adanya Putusan MK Nomor 137/PUU-XIII/2015 dan 56/PUUXIV/2016 tentunya menjadi sangat terbatas. Oleh karenanya, dengan berlakunya Permenkumham Nomor 32 Tahun 2017 setidaknya dapat dimanfaatkan sebagai momentum hadirnya instrumen baru yang dapat digunakan oleh Pemerintah Pusat dalam rangka pengawasan terhadap Perda (di samping evaluasi dan fasilitasi) serta masyarakat itu sendiri.

\section{Simpulan}

Bentuk pengawasan perda akibat dari adanya Putusan MK Nomor 137/PUU-XIII/2015 dan 56/PUUXIV/2016, praktis kini hanya pengawasan yang bersifat preventif (executive preview) melalui mekanisme evaluasi terhadap beberapa raperda tertentu dan fasilitasi yang diberlakukan terhadap semua perda yang tidak dievaluasi dalam rangka pembinaan. Di samping itu, adanya putusan MK tersebut telah memposisikan MA sebagai satu-satunya lembaga berwenang membatalkan perda melalui mekanisme Pengujian Peraturan Perundang-Undangan (Hak Uji Materiil/ Judicial Review). Namun demikian, diundangkannya Permenkumham Nomor 32 Tahun 2017 tentang Tata Cara Penyelesaian Sengketa Peraturan Perundangundangan Melalui Jalur Nonlitigasi seolah menjadi jawaban dari Pemerintah atas terbitnya dua Putusan MK yang telah menghapuskan kewenangan 
Pemerintah untuk membatalkan perda. Dalam konteks pengawasan Perda, setidaknya penyelesaian sengketa berdasarkan

Permenkumham Nomor 32 Tahun 2017 dapat digunakan sebagai salah satu instrumen dalam rangka memperbaiki kualitas regulasi khususnya di tingkat daerah. Permenkumham Nomor 32 Tahun 2017 merupakan sebuah terobosan yang tepat, terlebih lagi jika hal ini dipandang sebagai salah satu upaya dalam menata regulasi di tingkat daerah terlepas dari masih perlunya pengkajian-pengkajian lebih lanjut guna optimalisasi pelaksanaan Permenkumham tersebut. Di samping itu, mekanisme penyelesaian sengketa peraturan perundang-undangan melalui jalur nonlitigasi dapat menjadi media alternatif bagi masyarakat yang merasa dirugikan atas berlakunya suatu perda di samping mekanisme judicial review yang menjadi kewenangan MA. Sedangkan bagi Pemerintah sendiri mekanisme ini dapat digunakan sebagai instrumen pengawasan, meskipun tidak bersifat aktif karena berdasarkan permohonan, serta juga tidak represif karena hasilnya bukan dalam bentuk penangguhan atau pembatalan terhadap perda melainkan lebih bersifat korektif dalam bentuk rekomendasi kepada Presiden. Adapun saran yang dapat dikemukakan dalam hal ini adalah bahwa dalam rangka menjaga agar karakteristik suatu peraturan daerah yang dibentuk oleh pemerintah daerah tetap berdasarkan prinsipprinsip penyelenggaraan otonomi dalam konteks negara kesatuan, maka perlu didukung dengan adanya penguatan pada mekanisme pengawasan preventif (executive preview) yang dimiliki oleh Pemerintah Pusat. Mekanisme pemberian nomor register oleh Menteri Dalam Negeri untuk Perda Provinsi, dan oleh Gubernur untuk Perda Kabupaten/ Kota dapat dimanfaatkan sebagai proses 'double check' untuk melakukan pencermatan kembali terhadap seluruh materi muatan perda apakah telah dilakukan penyempurnaan sesuai dengan hasil evaluasi/ fasilitasi atau tidak. Dengan demikian, keinginan bersama untuk 
menciptakan perda yang implementatif, tidak bertentangan dengan peraturan perundangundangan, selaras dengan arah kebijakan dan politik hukum nasional serta mencerminkan keadilan dan perlindungan hukum kepada masyarakat niscaya akan dapat tercapai.

\section{Daftar Pustaka}

Asshiddiqie, Jimly, Model-model Pengujian Konstitusional di Berbagai Negara, Konstitusi Press, Jakarta, 2005.

Konstitusi dan Konstitusionalisme Indonesia, Sekretariat Jenderal dan Kepaniteraan MK RI, Jakarta, 2006.

Pengujian Undang-Undang, Konstitusi Press, Jakarta, 2006.

Hukum Tata Negara Indonesia Pasca Reformasi, Bhuana Ilmu Populer, Jakarta, 2007.

Astawa, I Gde Pantja, Problematika Hukum Otonomi Daerah di Indonesia, Alumni, Bandung, 2008.

Hadjon, Philipus M., Perlindungan Hukum Bagi Rakyat di Indonesia, Peradaban, Surabaya, 2007.
Laksono, Fajar et al., Implikasi dan Implementasi Putusan Mahkamah Konstitusi Nomor 5/PUU-X/2012 tentang Sekolah Bertaraf Internasional (SBI)/ Rintisan Sekolah Bertaraf Internasional (RSBI), Pusat Penelitian dan Pengkajian Perkara, Pengelolaan Teknologi Informasi dan Komunikasi Kepaniteraan dan Sekretariat Jenderal Mahkamah Konstitusi RI, Jakarta, 2013.

Manan, Bagir, Menyongsong Fajar Otonomi Daerah, Cetakan 4, Pusat Studi Hukum FH-UII, Yogyakarta, 2005.

Marzuki, Peter Mahmud, Penelitian Hukum, Edisi Revisi, Kencana Prenada Media Group, Jakarta, 2016.

Nasution, Adnan Buyung, Arus Pemikiran

Konstitusionalisme: Hukum dan Peradilan, Kata Hasta Pustaka, Jakarta, 2007.

Salman, Radian, Pengujian Peraturan Daerah oleh Badan Peradilan, Hand Out, disampaikan pada Pelatihan Perancangan Produk Hukum Daerah yang Ramah Investasi dan Berbasis Bhineka Tunggal Ika, Fakultas Hukum Universitas Airlangga, Surabaya, 23-24 Mei 2017.

Sesung, Rusdianto, Hukum Otonomi Daerah: Negara Kesatuan, Daerah Istimewa, dan Daerah Otonomi Khusus, PT. 
Refika Aditama, Bandung, 2013.

Sihombing, Eka NAM, Perkembangan Kewenangan Pembatalan Peraturan Daerah dan Peraturan Kepala Daerah: Kajian Putusan Mahkamah Konstitusi Nomor 137/PUU$X I I / 2015$ dan Nomor 56/PUXIV/2016, Jurnal Yudisial Vol. 10 No. 2, Agustus 2017.

Sirajuddin, et.al., Hukum Administrasi Pemerintahan Daerah, Setara Press, Malang, 2016.

Soebechi, Imam, Hak Uji Materiil, Cetakan 1, Sinar Grafika, Jakarta, 2016.

Sukardi, Pembatalan Peraturan Daerah dan Akibat Hukumnya, Disertasi, Program Pascasarjana Universitas Airlangga, Surabaya, 2009.

Sukriono, Didik, Hukum Konstitusi dan Konsep Otonomi : Kajian Politik Hukum tentang Konstitusi, Otonomi Daerah dan Desa Pasca Perubahan Konstitusi, Setara Press, Malang, 2013.

Supanca, Ida Bagus Rahmadi, Sebuah Gagasan tentang Grand Design Reformasi Regulasi Indonesia, Universitas Katolik Indonesia Atma Jaya, Jakarta, 2017.
Wade, Sir William and Christopher Forsyth, Administrative Law, eighth edition, Oxford University Press, New York, 2000 